\title{
Stabilization of the p53 tumor suppressor is induced by adenovirus 5 E1A and accompanies apoptosis
}

\author{
Scott W. Lowe ${ }^{1}$ and H. Earl Ruley ${ }^{2,3}$ \\ ${ }^{1}$ Center for Cancer Research and Department of Biology, Massachusetts Institute of Technology, Cambridge, Massachusetts \\ $02139 \mathrm{USA}_{i}{ }^{2}$ Department of Microbiology and Immunology, Vanderbilt University School of Medicine, \\ Nashville, Tennessee 37232-2363 USA
}

\begin{abstract}
Oncogenic transformation by human adenoviruses requires early regions $1 \mathrm{~A}$ and $1 B$ (E1A and E1B) and provides a model of multistep carcinogenesis. This study shows that the metabolic stabilization of p53 observed in adenovirus 5 (Ad5)-transformed cells can occur in untransformed cells expressing E1A alone. Stabilized p53 was localized to the nucleus and was indistinguishable from wild-type p53 with respect to its interactions with hsc70, PAb420, Ad5 $\mathrm{p}^{55^{\mathrm{EB}}}$, and SV40 large T antigen. Moreover, binding of Ad5 p55 ${ }^{\mathrm{E} 1 \mathrm{~B}}$ or SV40 large $T$ antigen had no additional effect on p53 levels or turnover. Higher levels of p53 were also induced in a variety of cell types within $40 \mathrm{hr}$ after transferring E1A genes. E1A also caused cells to lose viability by a process resembling apoptosis. The apoptosis appeared to involve p53, because p53 levels reverted to normal in surviving cells that had lost E1A, and E1B protected cells from the toxic effects of E1A. These results suggest that (1) the involvement of $\mathrm{p} 53$ in tumor suppression and/or apoptosis can be regulated at the level of protein turnover, and (2) a major oncogenic role for E1B is to counter cellular responses to E1A (i.e., stabilization of $\mathbf{p 5 3}$ and associated apoptosis) that preclude transformation by E1A alone. This represents the first physiological setting in which high levels of endogenous p53 are induced in response to an oncogenic challenge, with the apparent consequence of suppressing transformation.
\end{abstract}

[Key Words: p53 tumor suppressor; adenovirus 5; E1A; apoptosis]

Received December 9, 1992; revised version accepted January 21, 1993.

p53 was identified as a cellular protein associated with simian virus 40 (SV40) large $\mathrm{T}$ antigen (Lane and Crawford 1979; Linzer and Levine 1979) and later with the adenovirus 5 early region $1 \mathrm{~B}$ (Ad5 $\mathrm{p} 55^{\mathrm{E} 1 \mathrm{~B}}$ ) and human papilloma virus (HPV) types 16 and 18 E6 proteins (Sarnow et al. 1982; Werness et al. 1990). Although the gene was originally classified as a dominant-acting oncogene, current evidence indicates that p53 functions primarily as a tumor suppressor (Malkin et al. 1990; Srivastava et al. 1990; Levine et al. 1991; Donehower et al. 1992).

Mechanisms whereby p53 protects against neoplastic growth are unknown. Forced overexpression of wild-type p53 can suppress cell growth (Eliyahu et al. 1989; Finlay et al. 1989) and promote cell death by apoptosis (YonishRouach et al. 1991; Shaw et al. 1992). However, the relevance of these experiments to the natural circumstances in which p53 participates in tumor suppression and/or apoptosis is unknown, because physiological changes in p53 levels or activity that might mediate cellular resistance to oncogenic transformation have not been identified.

Interactions between viral early region proteins and

${ }^{3}$ Corresponding author. p53 also contribute to oncogenic transformation by human adenovinuses SV40 and HPV (Levine 1990). Given the role of p53 as a tumor suppressor, the viral tumor antigens are thought to interfere with p53 functions that preclude transformation. This is illustrated by the HPV E6 protein that promotes the proteolytic degradation of p53 (Scheffner et al. 1990). Similarly, stable complexes between $\mathrm{p} 53$ and $\mathrm{p} 55^{\mathrm{E} 1 \mathrm{~B}}$ may inactivate $\mathrm{p} 53$ function by sequestering the protein outside the nucleus (Zantema et al. 1.985 ) or by blocking interactions between p53 and other cellular targets (Yew and Berk 1992).

Because oncogenic transformation frequently involves the loss of p53 function, it seems paradoxical that the stability and levels of p53 are greatly increased in adenovirus- and SV40-transformed cells. Although the stabilization of p53 associated with viral tumor antigens may simply be coincidental, the phenomenon may have significance regarding p53 function or regulation. For example, p53 may have positive as well as negative effects on cell growth (Mercer et al. 1984; Shohat et al. 1987; Shaulsky et al. 1990; van den Heuvel et al. 1990). Thus, the tumor antigens could promote cell transformation, in part, by increasing the levels of p53. Alternatively, the stabilization of p53 may result from factors other than 
tumor antigen binding, possibly as part of a mechanism whereby cells attempt to resist viral transformation. Binding of the tumor antigen could allow transformation by countering the effects of increased p 53 expression.

Although evidence supporting this last model is limited, several studies suggest that tumor antigen binding may not stabilize p53. First, p53 turnover decreases in adenovirus type 12-transformed cells, even though the protein does not form a stable, immunoprecipitable complex with Ad12 p55 ${ }^{\mathrm{ElB}}$ (Zantema et al. 1985). Second, the half-lives of free and $T$ antigen-associated $\mathrm{p} 53$ are similar in SV40-transformed cells (Deppert and Haug 1986). In both cases, the effect of the tumor antigen on p53 turnover was attributed to metabolic changes associated with cell transformation, although neither study excluded the possibility of physical interactions between the tumor antigen and p53.

The present study analyzed p53 expression in normal and transformed REF52 cells. Although established as a permanent line, REF52 cells resemble primary cells in that transformation can require two or more oncogenes acting in concert (Ruley 1990). For example, REF52 cells are not transformed by either ras or adenovirus early region $1 \mathrm{~A}(\mathrm{E} 1 \mathrm{~A})$ individually but are oncogenically transformed by combinations of the two oncogenes (Franza et al. 1986). SV40 large T antigen and dominant transforming forms of p53 also transform in collaboration with ras (Hirakawa and Ruley 1988; Hicks et al. 1991). Because p53 is the only known cellular gene product with this activity in REF52 cells [Myc is inefficient (Kohl and Ruley 1987)l, we analyzed the effects of various oncogenes on cellular p53 expression. Quite unexpectedly, the half- life of endogenous p53 was extended in all cells expressing Ad5 E1 A. Moreover, the stabilization of p53 was associated with the selective loss of E1A-expressing cells by a process resembling apoptosis. Although it had no additional effect on p53 turnover, E1B protected cells against the toxic effects of E1A.

\section{Results \\ p53 levels are elevated in cell lines expressing adenovirus E1A}

p53 expression was analyzed in REF52 clones following immunoprecipitation using a broadly reactive anti-p53 antibody (PAb421). Cells expressing adenovirus E1A (clone 1A1) and cells transformed by T24 $\mathrm{H}$-ras and E1 A (e.g. RNA7) expressed significantly more p53 than the parental cell line (Fig. 1A). On average, the p53 levels in E1A-expressing clones were 10-fold higher than in REF52 cells and were similar to the levels expressed in 293 cells, a human cell line expressing adenovirus E1A and E1B. In 293 cells, a protein of $\sim 55 \mathrm{kD}$ coimmunoprecipitated with p53, indicating that p53 was complexed to Ad5 p55 ${ }^{\mathrm{E} 1 \mathrm{~B}}$ (Sarnow et al. 1982).

Steady-state levels of p53 are frequently elevated in naturally occurring tumor cells and in oncogenically transformed cell lines. In most cases, the increase results from point mutations that stabilize the protein (Eliyahu et al. 1988; Finlay et al. 1988; Hinds et al. 1989). Many, but not all, of the mutant proteins share similar conformational alterations: They express an epitope recognized by PAb240 (Gannon et al. 1990) and bind hsc70, a con-
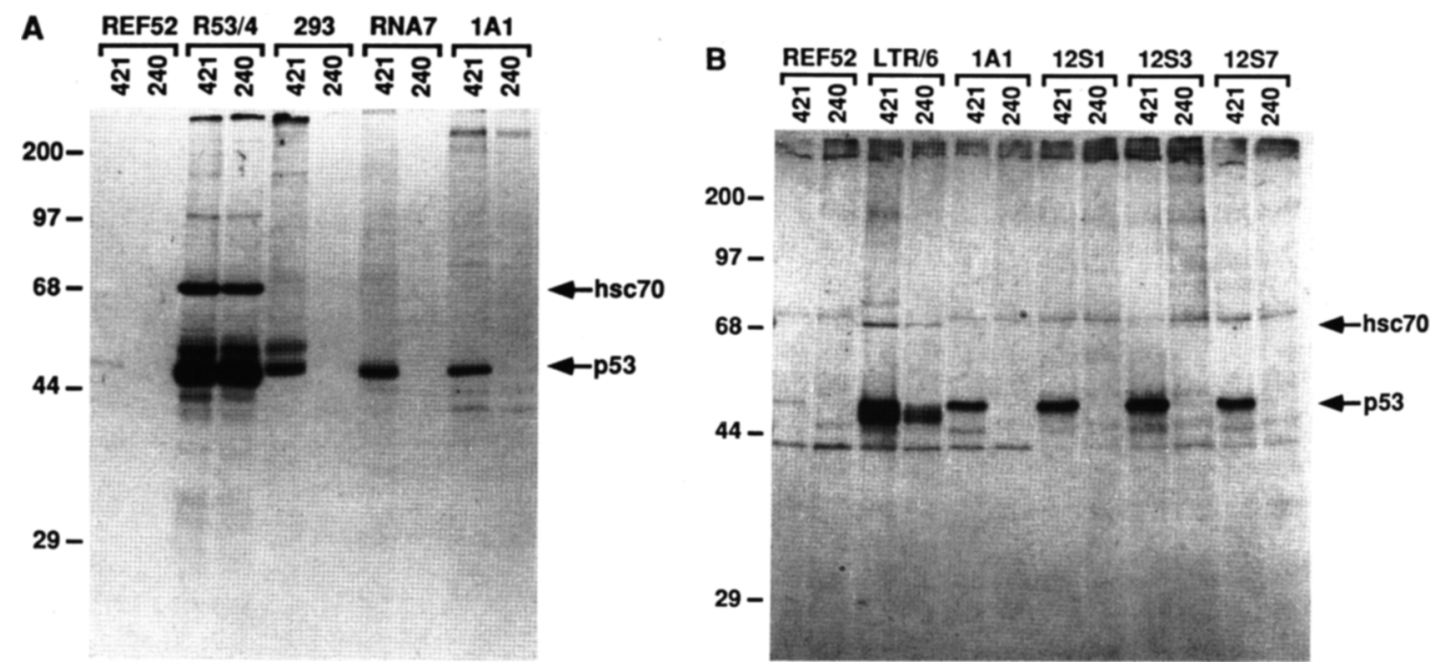

Figure 1. p53 levels in REF52 cells expressing adenovirus E1A. Cells were labeled for $4 \mathrm{hr}$ with ${ }^{35}$ S-labeled amino acids, and p53 was immunoprecipitated using either PAb421 (421) or PAb240 (240). The immunoprecipitated proteins were separated on 10\% SDSpolyacrylamide gels and visualized by fluorography. (A) p53 levels in cell lines expressing the entire Ad5 E1A gene. $(B)$ p53 levels in cell lines infected with a retrovirus expressing the $243 \mathrm{R}$ E1A protein, analyzed after minimal selection in culture $<20$ population doublings). (REF52) A rat embryo fibroblast line; (R53/4) REF52 clone transformed with T24 H-ras and p53 ${ }^{\text {Pro-193; }}$ (293) a human adenovinus-transformed cell line; (RNA7) REF52 cells transformed by T24 H-ras and E1 A; (1A1) REF52 clone expressing Ad5 ElA; (LTR/6) REF52 clone expressing p53 ${ }^{\mathrm{Val}-135}$; (12S1, 12S3, 12S7) REF52 clones expressing the $243 \mathrm{R}$ E1A protein. p53 and hsc70 are marked with arrows. The mobilities of molecular mass standards (in kilodaltons) are shown at Ieft of each gel. 
stitutively expressed member of the heat shock family (Pinhasi-Kimhi et al. 1986). For example, p53 from R53/4 cells (which express T24 H-ras and a mutant p53 gene, p53 ${ }^{\text {Pro-193 }}$ complexed to a $70-\mathrm{kD}$ protein and was immunoprecipitated with PAb240 (Fig. 1). In contrast, the p53 expressed in REF52, RNA7, and 1A1 cells neither associated with hsc70 nor reacted with PAb240 (Fig. 1A), suggesting that the p53 was wild type in conformation. Similar results were obtained with other REF52-derived cell lines expressing ElA (not shown).

\section{Increased p53 expression requires only the $12 S$ E1A product}

Differential splicing generates two E1A transcripts, designated $12 S$ and 13S, which encode proteins of 243 and 289 amino acids, respectively. Sequences required for oncogenic transformation are contained within the aminoterminal domain shared by the $289 \mathrm{R}$ and $243 \mathrm{R}$ proteins (Ruley 1990). Clones 1Al and RNA7 express both the 243R and 289R proteins (Franza et al. 1986). Therefore, to determine whether the $243 \mathrm{R}$ protein was sufficient to increase p53 levels, a $12 \mathrm{~S}$ cDNA was introduced into REF52 cells by retrovirus-mediated gene transfer, and p53 expression was assessed immediately after a sufficient number of cells were obtained for metabolic labeling $\left(1 \times 10^{6}\right.$ cells, obtained after 20 population doublings). p53 levels in 12S E1A-expressing cells (clones $12 S 1,12 \mathrm{~S} 3$, and $12 \mathrm{~S} 7\}$ were 10 times higher than the parental cell line (Fig. 1B), indicating that the 243R protein was sufficient for p53 induction. Unlike p53 $3^{\mathrm{Val}-135}$, none of the cellular p53s formed complexes with hsc 70 or reacted with PAb240.

\section{Nuclear localization of p53 in E1A-expressing cells}

The intracellular localization of $\mathrm{p} 53$ was examined by immunofluorescent staining (Fig. 2). The staining pattern in REF52 cells was relatively weak and predominantly nuclear. Moreover, most cells in the population expressed similar levels of p53. Likewise p53 was predominantly nuclear in cells expressing the entire E1A gene, only $12 \mathrm{~S} \mathrm{E} 1 \mathrm{~A}, \mathrm{~T} 24 \mathrm{H}$-ras and E1A, or T24 H-ras and $12 \mathrm{~S}$ E1A. However, anti-p53 fluorescence was considerably more intense and heterogeneous than in normal REF52 cells, suggesting that individual cells expressed variable levels of p53. Finally, cells transformed by E1A and E1B also expressed high levels of p53, but the protein localized within distinct perinuclear regions (Zantema et al. 1985). Each cell type displayed only minimal fluorescence when the primary antibody was omitted (data not shown).

\section{Elevated p53 levels in cells transiently expressing E1A}

p53 expression was monitored in primary mouse embryo fibroblasts by immunofluorescent staining $36-40 \mathrm{hr}$ after transferring E1A genes by DNA-mediated gene transfer (Fig. 3). A $\beta$-galactocidase gene ( $\mathrm{pCH} 110$ ) was introduced together with either E1A or control plasmids (e.g.,
pBluescript), to identify cells that had acquired exogenous DNA. The cells were stained with rabbit anti- $\beta$ galactosidase antibody and with murine antibodies specific for either E1A or p53, together with a mixture of anti-rabbit IgG (rhodamine) and anti-mouse IgG (fluorescein) secondary antibodies. Approximately $10 \%$ of the transfected cells expressed both E1A and $\beta$-galactocidase (Fig. 3A,B); and of these, $25-50 \%$ expressed discernibly higher levels of p53 (Fig. 3C,D). In contrast, higher levels of p53 were not induced in cells transfected with control plasmids (e.g., Bluescript) and pCH1 10 (Fig. 3E,F). Occasional cells that displayed anti-p53 fluorescence were present in both transfected and untransfected cultures and did not stain with anti- $\beta$-galactosidase. Similar results were also obtained following the transfer of E1A genes into REF52 and NIH-3T3 cells (data not shown), and high p53 levels were induced in HeLa cells infected with Ad5 mutants lacking E1B, as judged by Western blot analysis (E. White, pers. comm.). Thus, the induction of $\mathrm{p} 53$ by E1A is rapid and occurs in a variety of cell types.

\section{Binding of SV40 large T antigen to p53 in cells expressing E1A}

Oncogenic p53 variants lose the ability to bind SV40 large $\mathrm{T}$ antigen (Braithwaite et al. 1987; Wang et al. 19891. Consequently, various clones were infected by retroviruses expressing SV40 large T antigen and then analyzed for complexes containing both p53 and large $T$ antigen (Fig. 4). As expected, p53 levels in REF52 cells were elevated following the transfer of large $\mathrm{T}$ antigen, and p53 was quantitatively precipitated by using antibodies against large $T$ antigen (PAb419). In contrast, introduction of SV40 large $\mathrm{T}$ antigen into ElA-expressing cells (e.g., clone 1A1) had little additional effect on p53 levels, even though all of the p53 coprecipitated with large $T$ antigen. Thus, although SV40 large $T$ antigen and E1A increase p53 levels independently, the effects are not additive. Moreover, the p53 stabilized by E1A appears to maintain a wild-type conformation, capable of binding $T$ antigen.

\section{Binding of $p 55^{E 1 B}$ to $p 53$ in cells expressing E1A}

These observations suggest that the elevated levels of p53 in adenovirus-transformed cells might result largely, if not entirely, from E1A expression. To examine whether E1B had any additional effect on p53 levels or protein stability, cell lines expressing both E1A and E1B were constructed. Plasmids encoding Ad5 E1A and Ad5 E1B were introduced simultaneously into REF52 cells by cotransfection. Alternatively, E1B was introduced into cells already expressing E1A (clone 1A1). Clones were isolated in hygromycin, expanded, and analyzed after a limited number of passages.

$\mathrm{p} 53$ and $\mathrm{p} 55^{\mathrm{E} 1 \mathrm{~B}}$ were immunoprecipitated independently from $\left[{ }^{35} \mathrm{~S}\right]$ methionine-labeled cell lysates. All clones expressing E1A and E1B contained p53/p55 complexes, yet p53 levels were no higher than in cells 


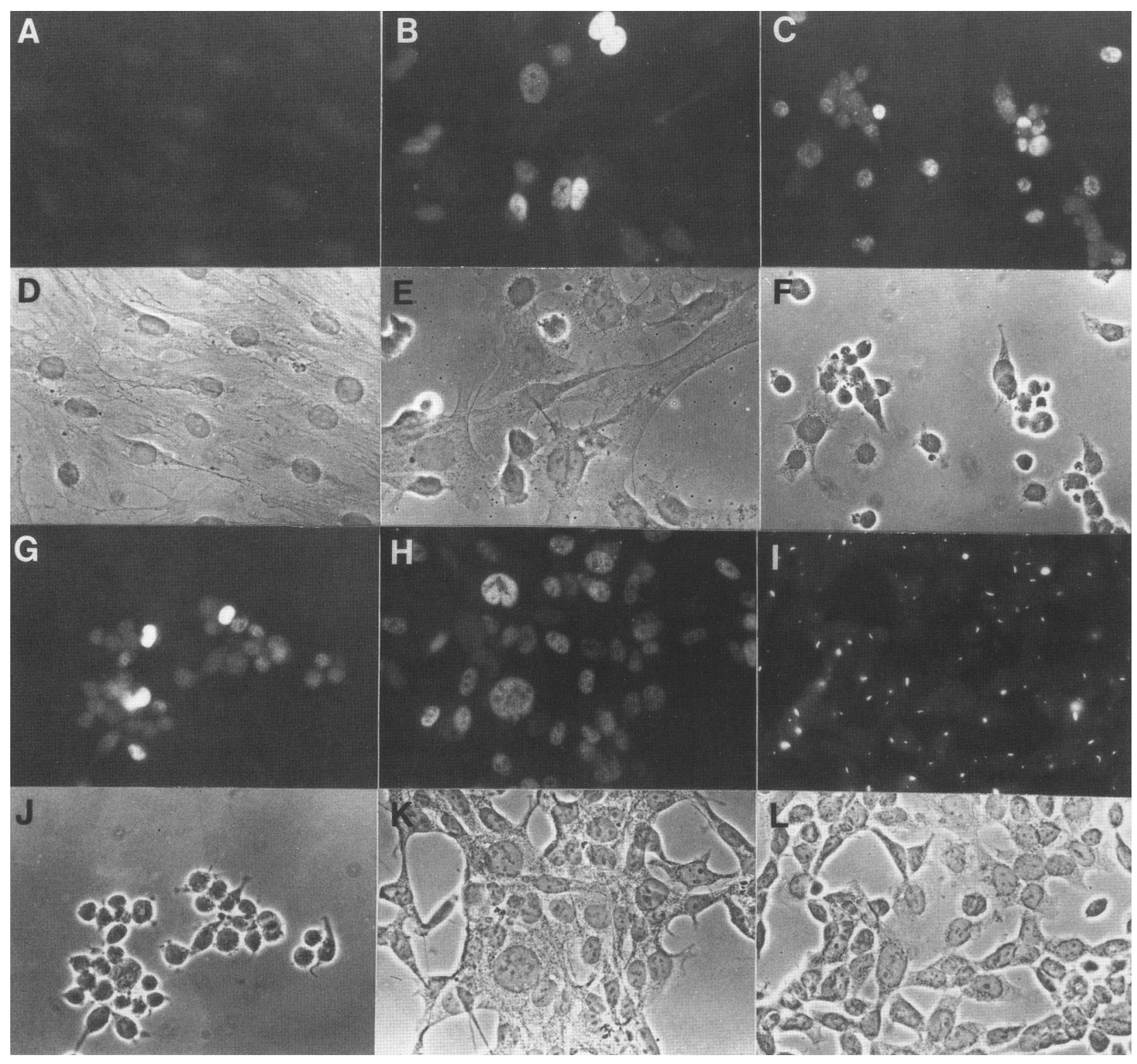

Figure 2. Localization of p53 in E1A-expressing cells. Cells were stained with PAb421 and FITC-labeled goat anti-mouse IgG. $(A, D)$ REF52 cells; $(B, E) 1 \mathrm{~A} 1$, a clone expressing Ad5 E1A; $(C, F) 12 S 1$, a clone expressing a 243R E1A cDNA; $(G, I)$ RNA9, a clone transformed by E1A and T24 H-ras; $(H, K)$ r12S-2, a clone transformed by $12 \mathrm{~S}$ E1A and T24 H-ras; $(I, L) 1 \mathrm{~A} 1 \mathrm{XX} 8$, a cell line derived following transfer of Ad5 E1B into 1A1 cells. Fluorescent images are shown above phase-contrast photomicrographs of the same field.

expressing E1A alone (Fig. 5). A protein of $\sim 155 \mathrm{kD}$ associated with the $\mathrm{p} 53 / \mathrm{p} 55^{\mathrm{E} 1 \mathrm{~B}}$ complex in cells expressing both E1A and ElB (Fig. 5). This protein coimmunoprecipitated with antibodies to either $\mathrm{p} 53$ or $\mathrm{p} 55^{\mathrm{E} 1 \mathrm{~B}}$; therefore, recovery of the $155-\mathrm{kD}$ protein did not result from antibody cross-reaction. The $155-\mathrm{kD}$ protein was not associated with p53 in REF52 cells or in cells expressing E1A or T24 H-ras and ElA, suggesting that the protein bound specifically to $\mathrm{p} 53 / \mathrm{p} 55^{\mathrm{E} 1 \mathrm{~B}}$ complexes.

Stabilization of p53 in cells expressing E1A

Levels of p53 gene transcripts and rates of protein turn- over were measured to determine the mechanism whereby p53 levels were increased. As judged by Northern blot analysis, E1A had no obvious effect on p53 gene transcription. The levels of p53 transcripts in cells transformed with T24 $\mathrm{H}$-ras and E1 A and cells expressing E1A or $12 \mathrm{~S}$ E1A were comparable to those present in normal REF52 cells (Fig. 6).

To examine p53 turnover, cells were labeled with $\left[{ }^{35} \mathrm{~S}\right] \mathrm{methionine}$ for $1 \mathrm{hr}$ and chased with excess unlabeled methionine for various times, and levels of labeled p53 were monitored by immunoprecipitation. Autoradiographs illustrating p53 turnover in representative clones are shown in Figure 7. The half-life of p53 in the 


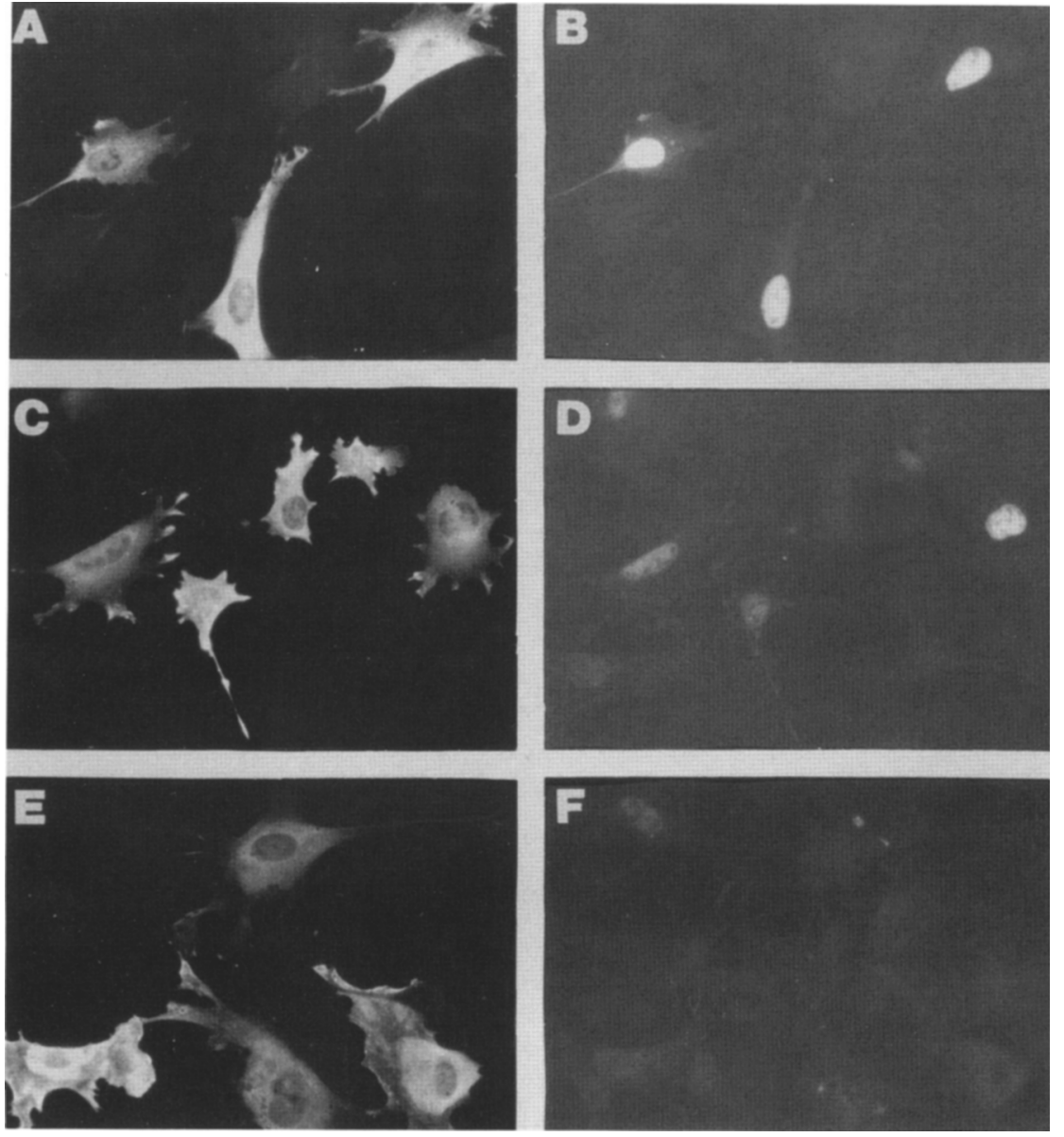

Figure 3. Induction of $\mathrm{p} 53$ following transient expression of ElA. Primary mouse embryo fibroblasts were cotransfected with $\mathrm{pCH} 110$ and either $\mathrm{plA}|A-D|$ or $\mathrm{pB}$ luescript $(E, F)$. After $36-40 \mathrm{hr}$, the cells were incubated with a rabbit anti- $\beta$-galactosidase antibody and with murine antibodies specific for either E1A or p53 and stained with a mixture of anti-rabbit IgG (rhodamine) and anti-mouse IgG (fluoroscein) secondary antibodies. Cells in the same field were photographed to show anti- $\beta$-galactosidase fluorescence $(A, C, E)$ and either anti-E1A $(B)$ or anti-p53 fluorescence $\{D, F\rangle$. parental line was $20-30 \mathrm{~min}$, consistent with previously reported values for wild-type protein (Gronostajski et al. 1984; Reich and Levine 1984). In contrast, p53 in clones expressing E1A were 5-10 times more stable, with halflives exceeding $2 \mathrm{hr}$. Moreover, p53 half-lives in cells expressing E1A and those expressing both E1A and E1B were not significantly different. p53 half-lives were similarly extended in clones expressing the $12 \mathrm{~S}$ E1A gene or transformed by E1A and T24 H-ras (not shown). This indicates that ElA is responsible for the increased stability of p53 in at least some cells transformed by human adenoviruses. However, we cannot exclude the possibility that E1B has an independent, but nonadditive, effect on p53 levels.

\section{Elevated p53 levels require continuous E1A expression}

ElA is selected against, such that clones transfected with E1A expression plasmids frequently lose the gene during serial passaging unless selection is maintained for a linked drug resistance gene or unless the cells are transformed by a collaborating oncogene (e.g., ras or E1B). In this study cells were allowed to lose ElA to study the association between E1A expression and high p53 levels.
Clone 1A1, derived from a neo-resistant colony following transfer of plAneo (Franza et al. 1986), was passaged twice weekly in the absence of G418. The cells quickly ( 3 weeks, $\sim 20$ population doublings) lost the epithelial morphology characteristically associated with E1A and became indistinguishable from the parental cells (not shown). Loss of E1A expression in the resulting cell population (designated $1 \mathrm{Al}_{\text {rev }}$ ) was demonstrated by immunoprecipitation using an E1A-specific monoclonal antibody (Fig. 8, right). Similarly, p53 levels in $1 \mathrm{~A} 1_{\text {rev }}$ cells were 10 -fold lower than the original $1 \mathrm{Al}$ clone, declining to the levels observed in normal REF52 cells (Fig. 8, left). These results indicate that the stabilization of p53 requires continuous E1A expression.

\section{Cells expressing E1A undergo apoptosis}

Recently, both E1A and p53 have been shown to induce apoptosis (Yonish-Rouach et al. 1991; Rao et al. 1992; Shaw et al. 1992; White et al. 1992). We therefore examined E1A-expressing REF52 cells for signs of apoptosis, namely, reduced viability of cells grown at high densities or in media containing low serum and degradation of genomic DNA. Cultures of ElA-expressing cells contained significant numbers of dead cells when main- 
Figure 4. Interactions between p53 and SV40 large $T$ antigen in cells expressing E1A. A temperature-conditional SV40 large $\mathrm{T}$ antigen (tsA58) was introduced into REF52 cells and clones expressing E1A. Cells were labeled for $4 \mathrm{hr}$ with 100 $\mu \mathrm{Ci} / \mathrm{ml}$ of ${ }^{35} \mathrm{~S}$-labeled amino acids at $33^{\circ} \mathrm{C}$, and p53/T antigen complexes were precipitated using monoclonal antibodies against $\mathrm{p} 53$ (PAb421) and large $\mathrm{T}$ antigen (PAb419). (WSR1) REF52 clone transformed by wild-type large $\mathrm{T}$ antigen and T24 H-ras; RNA7, a clone transformed by T24 H-ras and E1A; (1A1, 1AHy, 1A3) clones expressing Ad5 ElA. REF/T, $\mathrm{RNA} 7 / \mathrm{T}, 1 \mathrm{Al} / \mathrm{T}, 1 \mathrm{AHy} / \mathrm{T}$, and $1 \mathrm{~A} 3 / \mathrm{T}$ are cell populations derived from the same clones following infection with a retrovirus vector expressing tsA58. Bands corresponding to SV40 large $\mathrm{T}$ antigen (T) and p53 are indicated with arrows. The mobility of molecular size markers are shown at left.

tained in $10 \%$ FBS, as judged by trypan blue dye exclusion (Fig. 9A). In contrast, the viability of either REF52 cells or cells transformed by E1A and E1B was nearly $100 \%$. The viability of cells transformed by T24 H-ras and E1A was higher than that of cells expressing E1A alone, except at higher cell densities where the cultures contained similar proportions of dead cells (not shown). Death of E1A-expressing cells was particularly pronounced in media containing $0.5 \%$ calf serum. Although E1B protected against the loss of cell viability associated with E1A, T24 H-ras did not.

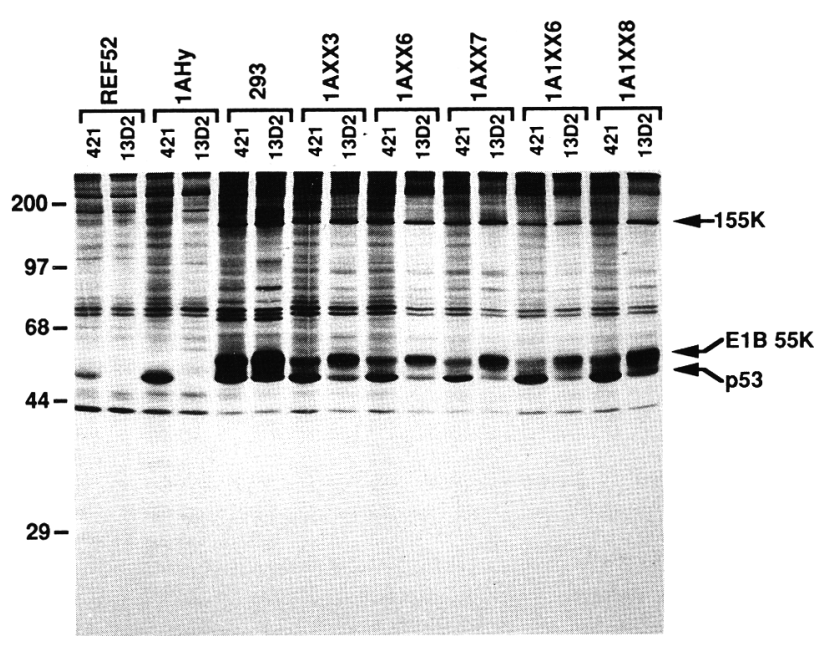

Figure 5. Interactions between $\mathrm{p} 53$ and $\mathrm{p} 55^{\mathrm{E} 1 \mathrm{~B}}$ in cells expressing ElA. Cells were labeled for $18 \mathrm{hr}$ with $100 \mu \mathrm{Ci} / \mathrm{ml}$ of ${ }^{35} \mathrm{~S}$ labeled amino acids; $53 / \mathrm{p} 55^{\mathrm{EIB}}$ complexes were precipitated using PAb421 (421) and 13D2, an antibody to $\mathrm{p} 55^{\mathrm{EIB}}$. (1AHy) A clone expressing Ad5 E1A; (293) human cells expressing Ad5 $\mathrm{E} 1 \mathrm{~A}$ and $\mathrm{E} 1 \mathrm{~B}$; (1AXX3, 1AXX6, 1AXX7) clones derived following cotransfection of E1A and E1B into REF52 cells; (1A1XX6, $1 \mathrm{~A} 1 \mathrm{XX} 8$ ) cell lines derived from clone $1 \mathrm{~A} 1$ following introduction of E1B. The mobilities of $\mathrm{p} 53, \mathrm{p} 55^{\mathrm{E} 1 \mathrm{~B}}$ and a coprecipitating $155-\mathrm{kD}$ protein are marked with arrows, and the mobilities of molecular size markers are indicated at left.
Genomic DNA was isolated from various clones 3 days after seeding in media containing $10 \%$ FBS or $0.5 \%$ calf serum and analyzed by agarose gel electrophoresis. DNA from E1A-expressing clones generated a "ladder" characteristic of intranucleosomal cleavage (Fig. 9B). DNA degradation was particularly pronounced when cells were maintained in low serum. When cultured in low serum, cells transformed by T24 H-ras and E1A also contained degraded DNA, whereas no DNA degradation was observed in normal REF52 cells or cells transformed by E1A and E1B.

\section{Discussion}

The stabilization of p53 in cells transformed by Ad5 has been thought to result from physical interactions with the $\mathrm{p} 55^{\mathrm{E} 1 \mathrm{~B}}$ tumor antigen or from changes associated with oncogenic transformation. However, this study

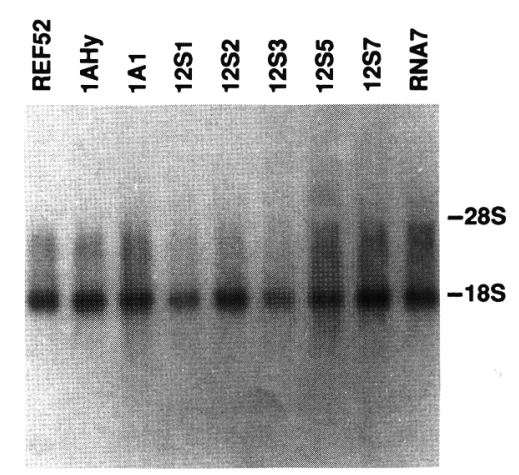

Figure 6. p53 gene expression. p53 transcripts were detected by northern blot analysis of total RNA following separation on a $1 \%$ agarose gel. A ${ }^{32} \mathrm{P}$-labeled rat p53 cDNA fragment was used as a probe. (1AHy, 1A1) REF52 cells containing Ad5 E1A; \{12S1, 12S2, 12S3, 12S5, and 12S7) clones expressing 12S E1A cDNA; (RNA7) cells transformed by T24 H-ras and Ad5 E1A. The locations of the $28 \mathrm{~S}$ and $18 \mathrm{~S}$ RNAs are shown at right. 


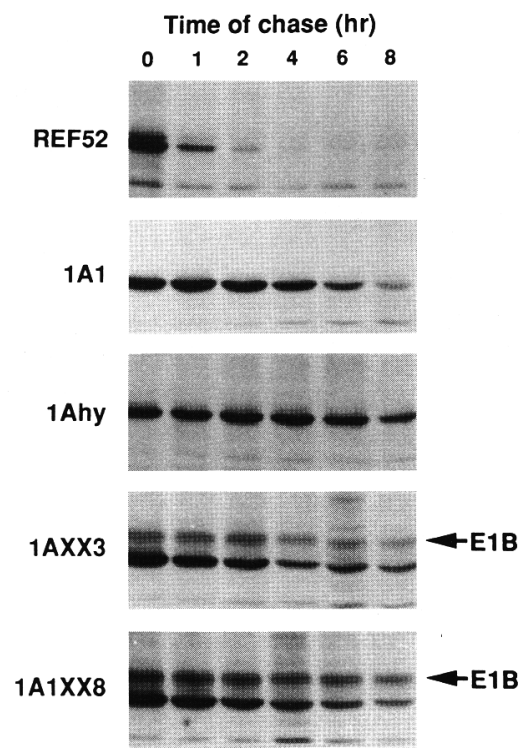

Figure 7. Stabilization of $\mathrm{p} 53$ in cells expressing E1A. Cells were incubated for $2 \mathrm{hr}$ with medium lacking methionine, labeled for $1 \mathrm{hr}$ with $100 \mu \mathrm{Ci} / \mathrm{ml}$ of ${ }^{35} \mathrm{~S}$-labeled amino acids, washed twice with PBS, and chased with excess unlabeled methionine. Cells were lysed at various times, and p53 was immunoprecipitated using PAb421. (1A1, 1AHy) Clones expressing Ad5 E1A; (1AXX3) REF52 clones derived by cotransfecting E1A and $\mathrm{E}_{1 \mathrm{~B}}$; $(1 \mathrm{~A} 1 \mathrm{XX} 8$ ) cell line derived from $1 \mathrm{Al}$ following transfer of E1B.

demonstrates that the metabolic stabilization of p53 can occur in untransformed cells expressing E1A alone. Neither transformation by ras nor binding of $\mathrm{p}^{\mathrm{E}} 5^{\mathrm{E} 1 \mathrm{~B}}$ or SV40 large $\mathrm{T}$ antigen extended the half-life of $\mathrm{p} 53$ beyond that observed in cells expressing ElA alone.

The mechanism whereby E1A increases the half-life of p53 is unknown. The effect is presumably indirect, as the two proteins are not known to interact physically (Egan et al. 1988; Whyte et al. 1989). Moreover, the effects of SV40 large T antigen and E1A on p53 turnover were not additive. Although the stabilized p53 was unaltered with regard to electrophoretic mobility, subcellular localization, or interactions with monoclonal antibodies and viral tumor antigens, we cannot exclude the possibility that $\mathrm{p} 53$ is modified in a manner that makes the protein less susceptible to proteolytic degradation. Alternatively, E1A may affect pathways involved in p53 turnover.

Previous studies have resulted in different conclusions concerning the roles of E1A and E1B (or transformation) on p53 levels and stability. The levels of 53 have been measured in cells expressing different segments of adenovirus early region 1 and have been correlated with the expression of E1B (Jochemsen et al. 1987; Mak et al. 1988; van den Heuvel et al. 1990) or E1A (Zantema et al. 1985). In each case, p53 stabilization was attributed to interactions with $\mathrm{p} 55^{\mathrm{E} 1 \mathrm{~B}}$ and/or changes associated with transformation. However, the correlation between p53 stability and E1B is probably indirect, because E1A ex- pression is typically much higher in cells cotransfected with E1A and E1B than in cells transfected with E1A alone \{van den Elsen et al. 1983b; Senear and Lewis 1986; Jochemsen al. 1987; Yoshida et al. 1987). Both cis- and trans-acting effects of E1B on E1A transcription have been reported (Natarajan 1986; Herrman et al. 1987; Jochemsen et al. 1987; Yoshida et al. 1987). The phenomenon may also reflect selection against cells expressing higher levels of E1A in the absence of E1B (Fig. 8).

Although mutations may stabilize p53, several observations indicate that the p53 induced by E1A is structurally wild type and therefore is biochemically competent to function as a tumor suppressor. First, p53 levels were elevated in all clones expressing E1A, including those analyzed $<48 \mathrm{hr}$ after transfer of E1A. These included cells (primary mouse embryo fibroblasts, mouse $3 \mathrm{~T} 3$ cells, and HeLa cells) known to contain only wildtype p53 genes. Second, in all 20 independent E1A-expressing clones analyzed, the stabilized p 53 was localized to the nucleus and did not associate with hsc70 or react with PAb240. Third, all of the p53 was capable of binding SV40 large $T$ antigen. Fourth, p53 levels reverted to normal as cells lost E1A, whereas it would be highly unlikely that the cells could concomitantly lose mutant p53 genes. Finally, mutant p53 genes enable ras to transform REF52 cells (Hicks et al. 1991), an unlikely interaction if the cells already contain mutant p53.

Recently, ElA has been found to induce a cytotoxic phenotype resembling apoptosis (White et al. 1991,1992; Rao et al. 1992). The phenomenon accounts for the DNA degradation ( $\mathrm{deg}$ ) and cytocidial (cyt) phenotypes associated with adenovirus strains containing mutations in the $19-k D$ E1B protein and probably contributes to the en-

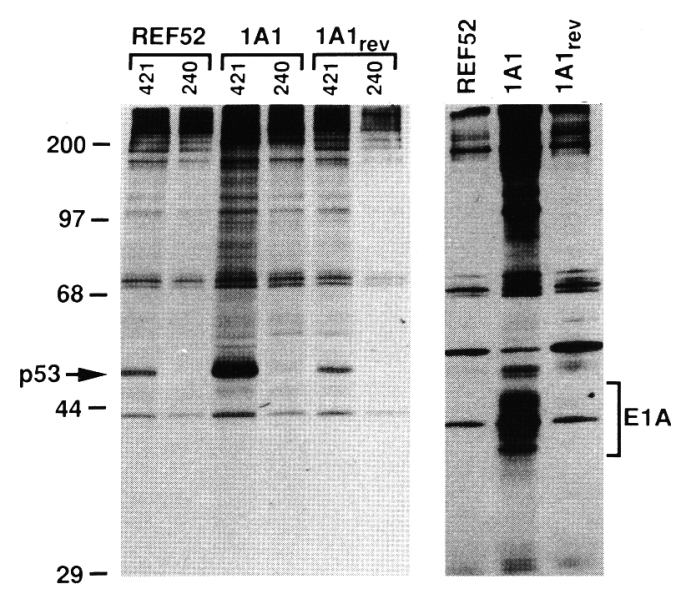

Figure 8. Elevated p53 levels require continuous E1A expression. Cells were labeled for $18 \mathrm{hr}$ with ${ }^{35} \mathrm{~S}$-labeled amino acids. p53 was precipitated using either PAb421 (421) or PAb240 (240), and E1A polypeptides were precipitated using monoclonal antibody M73. (REF52) The parental rat embryo fibroblast line; (1A1) REF52 cells expressing E1A and $1 \mathrm{~A} 1_{\text {rev }}$, derived by passaging $1 \mathrm{~A} 1$ cells for $\sim 20$ population doublings (six passages) in the absence of G418 selection. Autoradiographs illustrating levels of p53 (left) and E1A (right) are shown. The mobilities of p53, ElA, and molecular size markers are indicated. 

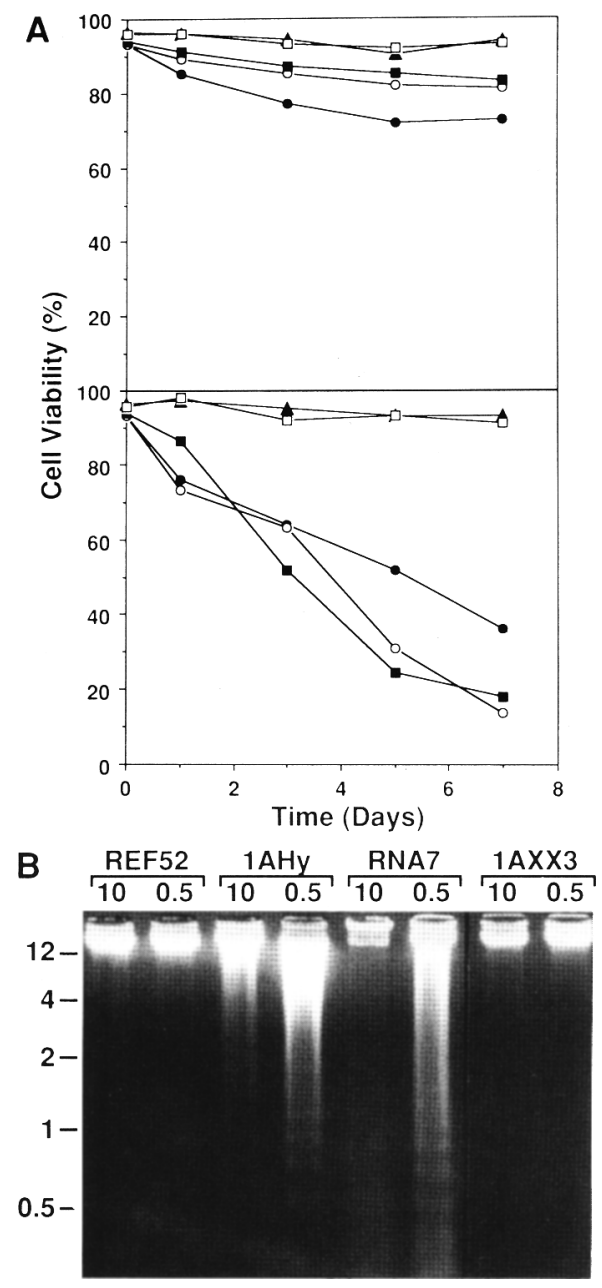

Figure 9. E1A-induced apoptosis. Cells $3 \times 10^{4}$ cells $/ 60$-mm dish) were seeded in $10 \%$ FCS (top) or $0.5 \%$ calf serum (bottom). At various times, the viability of floating and adherent cells was assessed by trypan blue exclusion. Fresh medium was added 3.5 days after seeding. (A) REF52; (O) Ad5 ElA; (O) 12S ElA; (ロ) T24 H-ras + E1A; (口) Ad5 E1A + Ad5 E1B. Each point represents the average from three independent cell clones. At least 200 cells were counted for each determination. (B) Cells $\left(2 \times 10^{5}\right.$ cells $/ 150-\mathrm{mm}$ dish) were seeded in $10 \%$ FCS or $0.5 \%$ calf serum. After 3 days, genomic DNA was isolated from both floating and adherent cells, fractionated by agarose gel electrophoresis, and stained with ethidium bromide. (REF52) Parental line; (1AHy) a clone expressing Ad5 E1 A; (RNA7) a clone transformed by T24 H-ras and E1A; $(1 \mathrm{AXX} 3)$ a clone transformed by ElA and E1B.

hanced sensitivity of E1A-expressing cells to killing by tumor necrosis factor- $\alpha$ (TNF- $\alpha$ ). Thus, the 19-kD E1B and Bcl-2 proteins each protect cells from ElA-induced apoptosis, and $\mathrm{p} 19^{\mathrm{E} 1 \mathrm{~B}}$ protects against killing by TNF- $\alpha$. Similarly, a significant proportion of REF52 cells expressing ElA are nonviable, such that the E1A gene is quickly lost during serial passaging. Cell death is particularly pronounced in low serum and is accompanied by DNA degradation, as is characteristic of cells undergoing apoptosis.
Several observations suggest that the stabilization of p53 mediates E1A-induced apoptosis. First, both E1A and p53 induce apoptosis (White et al. 1991, 1992, Rao et al. 1992; Shaw et al. 1992; Yonish-Rouach et al. 1991). Second, p53 stabilized by E1A is present in the nucleus and is structurally indistinguishable from the wild-type tumor suppressor protein. Third, p53 levels revert to normal as cells lose E1A. Fourth, E1B allows cells to tolerate E1A without affecting p53 levels. This also suggests that the stabilization of p53 is not simply a consequence of DNA degradation (Maltzman and Czyzyk 1984; Kastan et al. 1991) or apoptosis. Finally, in the report by Debbas and White (this issue), $\mathrm{p} 19^{\mathrm{E} 1 \mathrm{~B}}$ was found to protect cells from p53-induced apoptosis while a dominant-negative form of $\mathrm{p} 53$ ( $\mathrm{p} 53^{\text {val135}}$ ) allowed E1A to transform in the absence of E1B.

Myc, like ElA and dominant transforming forms of p53, can promote the establishment of primary cells into permanent lines and transform primary cells in collaboration with ras oncogenes (Ruley 1990). Whereas Myc can also induce apoptosis (Evan et al. 1992), E1A activities involved in both transformation and apoptosis in REF52 cells appear to be independent of c-myc. In particular, c-myc transcription is unaffected by E1A (Kohl and Ruley 1987), and the levels of c-myc transcripts decline when cells expressing E1A are exposed to conditions (low serum) that promote apoptosis (M. Ragozzino and H.E. Ruley, unpubl.). It will be important to test whether the half-life of $\mathrm{p} 53$ changes during Myc-induced apoptosis.

It is perhaps significant that $\mathrm{T} 24 \mathrm{H}$-ras did not completely protect against E1A-induced apoptosis, even though E1A is not selectively lost from cells cotransformed with T24 H-ras. Presumably, a selective advantage provided by ras and/or transformation compensates for cell losses owing to E1A. Because cells transformed by ras and E1A are highly tumorigenic, escape from apoptosis appears to be neither a prerequisite for, nor a consequence of, oncogenic transformation in vitro.

Two E1B proteins, $\mathrm{p} 55^{\mathrm{E} 1 \mathrm{~B}}$ and $\mathrm{p} 19^{\mathrm{E} 1 \mathrm{~B}}$, collaborate separately with E1A to transform cultured cells and contribute to the oncogenicity of human adenovinuses /Bernards et al. 1986; Barker and Berk 1987, White and Cipriani 1990). Both E1B proteins protect against the consequences of $\mathrm{p} 53$ stabilization. Binding of $\mathrm{p} 55^{\mathrm{E} 1 \mathrm{~B}}$ blocks p53 functions (Yew and Berk 1992) and sequesters the protein from the nucleus (Zantema et al. 1985). $\mathrm{p}^{19^{\mathrm{E} 1 \mathrm{~B}}}$ and, to a lesser extent, $\mathrm{p} 55^{\mathrm{E} 1 \mathrm{~B}}$, protect against E1A-induced apoptosis (Rao et al. 1992; White et al. 1992), and $\mathrm{p} 19^{\mathrm{E} 1 \mathrm{~B}}$ protects against p53-induced apoptosis (Debbas and White, this issuel. Thus, an important, if not the primary, oncogenic role of both E1B proteins is to counter cellular responses to ElA (i.e., stabilization of p53 and associated apoptosis) that preclude transformation by ElA alone. This would also explain why no transforming activities have been attributed to E1B in the absence of E1A (van den Elsen et al. 1983a).

In summary, p53 turnover can be regulated in response to ElA. This represents the first example of a physiological setting in which high levels of endogenous p53 are 
induced in response to an oncogenic challenge, with the apparent consequence of suppressing transformation. The stabilization of p53 appears to guard cells against unscheduled proliferation induced by E1A. Similarly, the stabilization of native p53 and associated apoptosis may provide a natural defense against tumor progression in vivo.

\section{Materials and methods}

\section{Cell culture}

REF52 cells were maintained in Dulbecco's modified Eagles medium (DMEM) supplemented with $5 \%$ fetal bovine serum (FBS), $5 \%$ calf serum, penicillin $(50 \mathrm{U} / \mathrm{ml})$, and streptomycin $(50 \mu \mathrm{g} /$ mll. REF52 cells expressing Ad5 E1A (e.g., clone 1A1) or transformed by T24 H-ras and E1A (e.g., clone RNA7) have been described (Franza et al. 1986). Clones R53/4 and 52LTR/6 expressed mutant $\mathrm{p} 53$ genes $\left[\mathrm{p} 53^{\text {Pro-193 }}\right.$ and $\mathrm{p} 53^{\text {Val-135 }}$, respectively [Hicks et al. 1991)], and were obtained from Dr. Michael Mowat (Manitoba Institute of Cell Biology, Canada). $\psi 2$ cells producing the tsA58-3 and LJ-12S retroviruses (Jat and Sharp 1989) were maintained on DMEM containing $10 \%$ calf serum.

\section{Gene transfer}

Retroviruses expressing the Ad5 E1A 12S cDNA were isolated following transfection of pLJ-12S into $\psi 2$ cells. LJ-12S expresses a $12 S \mathrm{E} 1 \mathrm{~A} \mathrm{cDNA}$ and a neo gene from the viral long terminal repeat (LTR) and an SV40 early promoter, respectively (M. Timmers, unpubl.). Cells expressing LJ-12S were isolated in media supplemented with $0.4 \mathrm{mg} / \mathrm{ml}$ of G418.

The tsA58-3 retrovirus expresses a temperature-sensitive large $T$ antigen (tsA58) and neo (Jat and Sharp 1989). To introduce SV40 large $T$ antigen into clones already expressing neo, $5 \times 10^{6}$ ts A58-3 producer cells were $\gamma$-irradiated for $27 \mathrm{~min}$ (3000 rads) and cocultivated with $2 \times 10^{3}$ target cells for 3 days at $37^{\circ} \mathrm{C}$ in the presence of $2 \mu \mathrm{g} / \mathrm{ml}$ of polybrene. Colonies of infected target cells arose by 10 days at $37^{\circ} \mathrm{C}$ while the irradiated producer cells detached from the plate. Colonies were pooled and transferred to the permissive temperature for large $\mathrm{T}$ expression $\left(33^{\circ} \mathrm{C}\right)$ for at least 3 days before analysis. No cells remained in parallel cultures containing only irradiated producer cells.

Ad5 E1 A and E1B genes were introduced into cells by calcium phosphate coprecipitation. plAHygro (Ad5 E1A linked to a hygromycin B resistance gene) was cotransfected with p5XX (Ad5 $X b a I-X h o I$ genomic ElB fragment), and stable transfectants were isolated in medium containing $100 \mu \mathrm{g} / \mathrm{ml}$ of hygromycin B. Alternatively, p5XX was introduced into $1 \mathrm{Al}$ cells by cotransfecting pY3 (Blochinger and Diggelmann 1984) and selecting for hygromycin $B$ resistance. Stable lines were isolated and expanded in $25 \mu \mathrm{g} / \mathrm{ml}$ of hygromycin B. For transient expression studies, cells were transfected with pCH1 10 (Hall et al. 1983) and either plA (Franza et al. 1986) or pBluescript (Stratagene) plasmid DNAs (15 and $5 \mu \mathrm{g} / \mathrm{ml}$, respectively).

\section{Immunoprecipitation}

Monoclonal antibodies PAb419, PAb421, and M73 react with SV40 large $T$ antigen, $\mathrm{p} 53$, and adenovirus E1A, respectively (Harlow et al. 1981,1985). PAb240 reacts with most dominanttransforming forms of $\mathrm{p} 53$ but does not recognize wild-type p53 (Gannon et al. 1990|. 13D2 reacts with the $\mathrm{p} 55^{\mathrm{ElB}}$ product and was obtained from Dr. Eileen White (Rutgers University, NJ).
Cellular proteins were labeled with $100 \mu \mathrm{Ci} / \mathrm{ml}$ of ${ }^{35} \mathrm{~S}$-Express protein labeling mix (New England Nuclear) for either 4 or $18 \mathrm{hr}$ in methionine-free medium (Flow Labs) containing $5 \%$ dialyzed FBS. For 18-hour labelings, 5\% normal DMEM was included. Cell lysates were prepared (Hinds et al. 1987), normalized to equivalent trichloroacetic acid-precipitable counts (usually $2 \times 10^{7} \mathrm{cpm} /$, and cleared of nonspecific IgG-binding proteins (Harlow et al. 1986). p53, large T antigen, and E1B (Hinds et al. 1987) and ElA proteins (Harlow et al. 1986) were precipitated, fractionated on $10 \%$ SDS-polyacrylamide gels, and visualized by fluorography. Signal intensities were quantified using a Molecular Dynamics PhosphorImager and ImageQuant software.

For pulse-chase experiments, $5 \times 10^{5}$ cells were seeded into $100-\mathrm{mm}$ dishes and allowed to adhere overnight. Dishes were washed twice with phosphate-buffered saline (PBS) and incubated in the presence of methionine-free medium for $2 \mathrm{hr}$. Cultures were pulse-labeled for $1 \mathrm{hr}$ with $200 \mu \mathrm{Ci}$ of ${ }^{35} \mathrm{~S}$-labeled amino acids, washed twice with PBS, and chased for various times with normal growth medium supplemented with $10 \mathrm{~mm}$ unlabeled methionine. At various intervals, cells were lysed and the amount of labeled p53 was determined by immunoprecipitation as described above.

\section{Immunofluorescence}

For immunofluorescence experiments, cells were seeded on glass coverslips at subconfluent densities and allowed to adhere overnight. The cells were washed twice with PBS and fixed in freshly prepared formaldehyde solution [4\% (wt/vol) paraformaldehyde and $0.4 \%$ (vol $/ \mathrm{vol})$ picric acid in PBS]. After $15 \mathrm{~min}$ at room temperature, the fixed cells were washed in PBS, permeablized in methanol/acetone $\{1: 1\}$ for $2 \mathrm{~min}$, and washed again in PBS. To minimize nonspecific staining, the coverslips were preincubated in PBS containing 5\% goat serum for $1 \mathrm{hr}$ at room temperature. The primary antibody (PAb421 hybridoma tissue culture supernatant diluted $1: 10$ in PBS/5\% goat serum/ was applied to the coverslips, and the samples were incubated for 2 hr at $37^{\circ} \mathrm{C}$. Subsequently, the coverslips were washed in PBS and incubated with fluorescein isothiocyanate (FITC)-labeled goat anti-mouse IgG ( $1: 200$ dilution in PBS $/ 5 \%$ goat serum; Calbiochem] for $20 \mathrm{~min}$ at $37^{\circ} \mathrm{C}$. Finally, the samples were washed extensively in PBS $/ 0.2 \%$ Tween 20 and mounted in PBS/glycerol $(1: 3)$ containing $0.1 \% \quad(w t / v o l) p$-phenlyenediamine (Sigma). Control cultures were treated identically, except the primary antibody was omitted. Transiently transfected cells were analyzed in a similar manner except anti- $\beta$-galactosidase (Promega) and mixtures of primary (PAb421, PAb248, and PAb246 for p53, or M58 and M73 for E1A) and secondary (rhodamine/anti-rabbit IgG and fluorescein-anti-mouse IgG) antibodies were used.

\section{Cell viability}

Cells were seeded at $3 \times 10^{4}$ cells $/ 60-\mathrm{mm}$ dish in $10 \%$ FCS or $0.5 \%$ calf serum. At various times thereafter, floating and adherent cells were pooled, and viability was assessed by trypan blue exclusion. Fresh medium was added 3.5 days after seeding. At least 200 cells were counted for each determination. Degradation of genomic DNA was taken as evidence of cell death by apoptosis. Cells were seeded at $2 \times 10^{5}$ cells $/ 150-\mathrm{mm}$ dish in $10 \%$ FCS or $0.5 \%$ calf serum. After 3 days, genomic DNA was isolated from pools of floating and adherent cells and analyzed by agarose gel $(1 \%)$ electrophoresis.

\section{Acknowledgments}

We thank Dr. Eileen White for discussing her results before 
publication and Dr. David Housman for graciously allowing this work to be completed in his laboratory. This work was supported by grants (R01CA40602) from the National Cancer Institute to H.E.R. and partially supported by a Cancer Center Core grant (P30CA14051) to P.A. Sharp.

The publication costs of this article were defrayed in part by payment of page charges. This article must therefore be hereby marked "advertisement" in accordance with 18 USC section 1734 solely to indicate this fact.

\section{References}

Barker, D. and A.J. Berk. 1987. Adenovirus proteins from both E1B reading frames are required for transformation of rodent cells by viral infection and DNA transfection. Virology 156: 107-121.

Bernards, R., M.G.W. de Leeuw, A. Houweling, and A.J. van der Eb. 1986. Role of the adenovirus early region 1B tumor antigens in transformation and lytic infection. Virology 150: 126-139.

Blochinger, K. and H. Diggelmann. 1984. Hygromycin B phosphotransferase as a selectable marker for DNA transfer experiments with higher eucaryotic cells. Mol. Cell. Biol. 4; 2929-2931.

Braithwaite, A.W., H. Sturzbecher, C. Addison, C. Palmer, K. Rudge, and J.R. Jenkins. 1987. Mouse p53 inhibits SV40 origin-dependent DNA replication. Nature 329: 458-460.

Deppert, W. and M. Haug. 1986. Evidence for free and metabolically stable p53 protein in nuclear subfractions of simian virus 40-transformed cells. Mol. Cell. Biol. 6: 2233-2240.

Donehower, L.A., M. Harvey, B.L. Slagle, M.J. McArthur, C.A. Montgomery, J.A. Butel, and A. Bradley. 1992. Mice deficient for p53 are developmentally normal but susceptible to spontaneous tumours. Nature 356: 215-220.

Egan, C., T.N. Jelsma, J.A. Howe, S.T. Bayley, B. Ferguson, and P.E. Branton. 1988. Mapping of cellular protein-binding sites on the products of early-region $1 \mathrm{~A}$ of human adenovirus type 5. Mol. Cell. Biol. 8: 3955-3959.

Eliyahu, D., N. Goldfinger, O. Pinhasi-Kimhi, Y. Skurnik, N. Arai, V. Rotter, and M. Oren. 1988. Meth A fibrosarcoma cells express two transforming mutant p53 species. Oncogene 3: 313-321.

Eliyahu, D., D. Michalovitz, S. Eliyahu, O. Pinhasi-Kimhi, and M. Oren. 1989. Wild-type p53 can inhibit oncogene-mediated focus formation. Proc. Natl. Acad. Sci. 86: 8763-8767.

Evan, G.I., A.H. Wyllie, C.S. Gilbert, T.D. Littlewood, H. Land, M. Brooks, C. Waters, L.Z. Penn, and D.C. Hancock. 1992. Induction of apoptosis in fibroblasts by $\mathrm{c}-\mathrm{myc}$ protein. Cell 69: 119-128.

Finlay, C.A., P.W. Hinds, and A.J. Levine. 1989. The p53 protooncogene can act as a suppressor of transformation. Cell 57: 1083-1093.

Finlay, C.A., P.W. Hinds, T.-H. Tan, D. Eliyahu, M. Oren, and A.J. Levine. 1988. Activating mutations for transformation by $\mathrm{p} 53$ produce a gene product that forms an hsc70-p53 complex with an altered half-life. Mol. Cell. Biol. 8: 531-539.

Franza, B.R. Jr., K. Maruyama, J.I. Garrels, and H.E. Ruley. 1986. In vitro establishment is not a sufficient prerequisite for transformation by activated ras oncogenes. Cell 44: 409418.

Gannon, J.V., R. Greaves, R. Iggo, and D.P. Lane. 1990. Activating mutations in $\mathrm{p} 53$ produce a common conformational effect. A monoclonal antibody specific for the mutant form. EMBO I. 9: 1595-1602.

Gronostajski, R.M., A.L. Goldberg, and A.B. Pardee. 1984. En- ergy requirement for degradation of tumor-associated protein p53. Mol. Cell. Biol. 4: 442-448.

Hall, C., E. Jacob, G. Ringold, and F. Lee. 1983. Expression and regulation of Escherichia coli lacZ gene fusions in mammalian cells. J. Mol. Appl. Genet. 2: 101-109.

Harlow, E., L.V. Crawford, D.C. Pim, and N.M. Williamson. 1981. Monoclonal antibodies specific for simian virus 40 tumor antigens. J. Virol. 39: 861-869.

Harlow, E., J.B.R. Franza, and C. Schley. 1985. Monoclonal antibodies specific for adenovirus early region $1 \mathrm{~A}$ proteins: Extensive heterogeneity in early region $1 \mathrm{~A}$ products. I. Virol. 55: 533-546.

Harlow, E., P. Whyte, J.B.R. Franza, and C. Schley. 1986. Association of adenovirus early-region 1A proteins with cellular polypeptides. Mol. Cell. Biol. 6: 1579-1589.

Herrman, C.H., C.V. Dery, and M.B. Mathews. 1987. Transactivation of host and viral genes by the adenovirus E1B $19 \mathrm{~K}$ tumor antigen. Oncogene 2: 25-35.

Hicks, G.G., S.E. Egan, A.H. Greenberg, and M. Mowat. 1991. Mutant p53 tumor suppressor alleles release ras-induced cell cycle growth arrest. Mol. Cell. Biol. 11: 1344-1352.

Hinds, P.W., C.A. Finlay, A.B. Frey, and A.J. Levine. 1987. Immunological evidence for the association of $\mathrm{p} 53$ with a heat shock protein, hsc70, in p53-plus-ras-transformed cell lines. Mol. Cell. Biol. 7: 2863-2869.

Hinds, P., C. Finlay, and A.J. Levine. 1989. Mutation is required to activate the p53 gene for cooperation with the ras oncogene and transformation. $/$. Virol 63: 739-746.

Hirakawa, T. and H.E. Ruley. 1988. Rescue of cells from ras oncogene-induced growth arrest by a second, complementing, oncogene. Proc. Natl. Acad. Sci. 85: 1519-1523.

Jat, P.S. and P.A. Sharp. 1989. Cell lines established by a temperature-sensitive Simian virus 40 large-T-antigen gene are growth restricted at the nonpermissive temperature. Mol. Cell. Biol. 9: 1672-1681.

Jochemsen, A.G., L.T.C. Peltenburg, M.F.W. te Pas, C.M. de Wit, and A.J. van der Eb. 1987. Activation of adenovirus 5 ElA transcription by region E1B in transformed primary rat cells. EMBO J. 6: 3399-3405.

Kastan, M.B., O. Onyekwere, D. Sidransky, B. Vogelstein, and R.W. Craig. 1991. Participation of p53 protein in the cellular response to DNA damage. Cancer Res. 51: 6304-6311.

Kohl, N.E. and H.E. Ruley. 1987. Role of c-myc in the transformation of REF52 cells by viral and cellular oncogenes. Oncogene 2: 41-48.

Lane, D.P. and L.V. Crawford. 1979. T antigen is bound to a host protein in SV40-transformed cells. Nature 278: 261-263.

Levine, A.J. 1990. The p53 protein and its interactions with the oncogene products of the small DNA tumor viruses. Virology 177: 419-426.

Levine, A.J., J. Momand, and C.A. Finlay. 1991. The p53 tumour suppressor gene. Nature 351: 453-456.

Linzer, D.I.H. and A.J. Levine. 1979. Characterization of a 54K dalton cellular SV40 tumor antigen present in SV40 transformed cells and uninfected embryonal carcinoma cells. Cell 17: 43-52.

Mak, I., S. Mak, and S. Benchimol. 1988. Expression of the cellular p53 protein in cells transformed by adenovirus 12 and viral DNA fragments. Virology 163: 201-204.

Malkin, D., F.P. Li, L.C. Strong, J. Fraumeni J. F., C.E. Nelson, D.H. Kim, J. Kassel, M.A. Gryka, F.Z. Bischoff, M.A. Tainsky, and S.H. Friend. 1990. Germ line p53 mutations in a familial syndrome of breast cancer, sarcomas, and other neoplasms. Science 250: 1233-1238.

Maltzman, W. and L. Czyzyk. 1984. UV irradiation stimulates levels of p53 cellular tumor antigen in nontransformed 
mouse cells. Mol. Cell. Biol. 4: 1689-1694.

Mercer, W.E., C. Avignolo, and R. Baserga. 1984. Role of the p53 protein in cell proliferation as studied by microinjection of monoclonal antibodies. Mol. Cell. Biol. 4: 276-281.

Natarajan, V. 1986. Adenovinus-2 E1a and Elb gene products regulate enhancer mediated transcription. Nucleic Acids Res. 14: 9455-9456.

Pinhasi-Kimhi, O., D. Mochalovitz, A. Ben-Zeev, and M. Oren. 1986. Specific interaction between the p53 cellular tumor antigen and major heat shock proteins. Nature 320: 182185.

Rao, L., M. Debbas, P. Sabbatini, D. Hockenbery, S. Korsmeyer, and $E$. White. 1992. The adenovirus ElA proteins induce apoptosis which is inhibited by the E1B $19 \mathrm{~K}$ and Bcl-2 proteins. Proc. Natl. Acad. Sci. 89: 7742-7746.

Reich, N.C. and A.J. Levine. 1984. Growth regulation of a cellular tumour antigen, p53, in nontransformed cells. Nature 308: 199-201.

Ruley, H.E. 1990. Transforming collaborations between ras and nuclear oncogenes. Cancer Cells 2: 258-268.

Sarnow, P., Y.S. Ho, J. Williams, and A.J. Levine. 1982. Adenovirus Elb-58kd tumor antigen and SV40 large tumor antigen are physically associated with the same $54 \mathrm{kd}$ cellular protein in transformed cells. Cell 28: 387-394.

Scheffner, M., B.A. Werness, J.M. Huibregtse, A.J. Levine, and P.M. Howley. 1990. The E6 oncoprotein encoded by human papillomavirus types 16 and 18 promotes the degradation of p53. Cell 63: 1129-1136.

Senear, A.W. and J.B. Lewis. 1986. Morphological transformation of estabished rodent cell lines by high level expression of the adenovirus type 2 Ela gene. Mol. Cell. Biol. 6: 12531260 .

Shaulsky, G., N. Goldfinger, A. Ben-Ze'ev, and V. Rotter. 1990. Nuclear accumulation of $\mathrm{p} 53$ protein is mediated by several nuclear localization signals and plays a role in tumorigenesis. Mol. Cell. Biol. 10: 6565-6577.

Shaw, P., R. Bovey, S. Tardy, R. Sahli, B. Sordat, and J. Costa. 1992. Induction of apoptosis by wild-type p53 in a human colon tumor-derived cell line. Proc. Natl. Acad. Sci. 89: 4495-4499.

Shohat, O., M. Greenberg, D. Reisman, M. Oren, and V. Rotter. 1987. Inhibition of cell growth mediated by plasmids encoding p53 anti-sense. Oncogene 1: 277-283.

Srivastava, S., Z. Zou, K. Pirollo, W. Blattner, and E. Chang. 1990. Germ-line transmission of a mutated p53 gene in a cancer-prone family with Li-Fraumeni syndrome. Nature 348: 747-749.

van den Elsen, P., A. Houweling, and A. van der Eb. 1983a. Expression of region Elb of human adenoviruses in the absence of region Ela is not sufficient for complete transformation. Virology 128: 377-390.

van den Elsen, P., A. Houweling, and A.J. van der Eb. 1983b. Morphological transformation of human adenoviruses is determined to a large extent by gene products of region E1A. Virology 131: 362-368.

van den Heuvel, S.J.L., T. van Laar, W.M. Kast, C.J.M. Melief, A. Zantema, and A.J. van der Eb. 1990. Association between the cellular p53 and the adenovirus 5 E1B-55 kd proteins reduces the oncogenicity of Ad-transformed cells. EMBO /. 9: 26212629.

Wang, E.H., P.N. Friedman, and C. Prives. 1989. The murine p53 protein blocks replication of SV40 DNA in vitro by inhibiting the initiation functions of SV40 large $\mathrm{T}$ antigen. Cell 57: 379-392.

Werness, B.A., A.J. Levine, and P.M. Howley. 1990. Association of human papillomavirus types 16 and 18 E6 proteins with p53. Science 248: 76-79.

White, E. and R. Cipriani. 1990. Role of adenovirus E1B proteins in transformation: Altered organization of intermediate filaments in transformed cells that express the 19-kilodalton protein. Mol. Cell. Biol. 10: 120-130.

White, E., R. Cipriani, and P. Sabbatini Denton, A. 1991. Adenovirus E1B 19-kilodalton protein overcomes the cytoxicity of E1A proteins. J. Virol. 65: 2968-2978.

White, E., P. Sabbatini, M. Debbas, W.M. Wold, D.I. Kusher, and L.R. Gooding. 1992. The 19-kilodalton adenovirus E1B transforming protein inhibits programmed cell death and prevents cytolysis by tumor necrosis factor $\alpha$. Mol. Cell. Biol. 12: 2570-2580.

Whyte, P., N.M. Williamson, and E. Harlow. 1989. Cellular targets for transformation by the adenovirus E1A proteins. Cell 56: $67-75$.

Yew, P.R. and A.J. Berk. 1992. Inhibition of p53 transactivation required for transformation by adenovirus early 1B protein. Nature 357: 82-85.

Yonish-Rouach, E., D. Resnitzky, J. Lotem, L. Sachs, A. Kimchi, and M. Oren. 1991. Wild-type p53 induces apoptosis of myeloid leukaemic cells that is inhibited by interleukin-6. $\mathrm{Na}$ ture 352: 345-347.

Yoshida, K., L. Vankatesh, M. Kuppuswany, and G. Chinnadurai. 1987. Adenovirus transforming $19-\mathrm{kD}$ T antigen has an enhancer-dependent trans-activation function and relieves enhancer repression mediated by viral and cellular genes. Genes \& Dev. 1: 645-658.

Zantema, A., P.I. Schrier, A. Davis-Olivier, T. van Laar, R.T.M.J. Vaessen, and A.J. van der Eb. 1985. Adenovirus serotype determines association and localization of the large E1B tumor antigen with cellular tumor antigen p53 in transformed cells. Mol. Cell. Biol. 5: 3084-3091. 


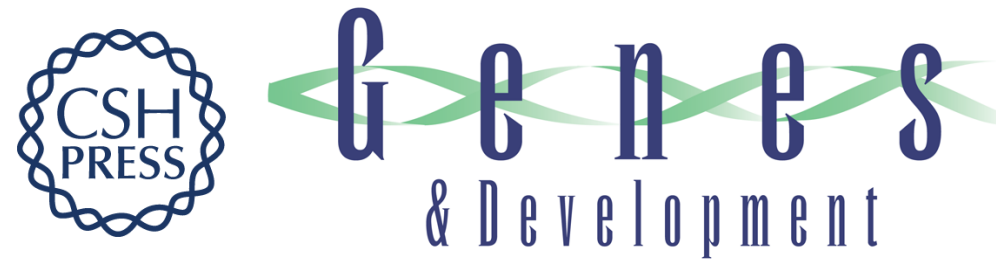

\section{Stabilization of the p53 tumor suppressor is induced by adenovirus 5 E1A and accompanies apoptosis.}

S W Lowe and H E Ruley

Genes Dev. 1993, 7:

Access the most recent version at doi:10.1101/gad.7.4.535

References This article cites 61 articles, 28 of which can be accessed free at:

http://genesdev.cshlp.org/content/7/4/535.full.html\#ref-list-1

License

Email Alerting

Service

Receive free email alerts when new articles cite this article - sign up in the box at the top right corner of the article or click here.

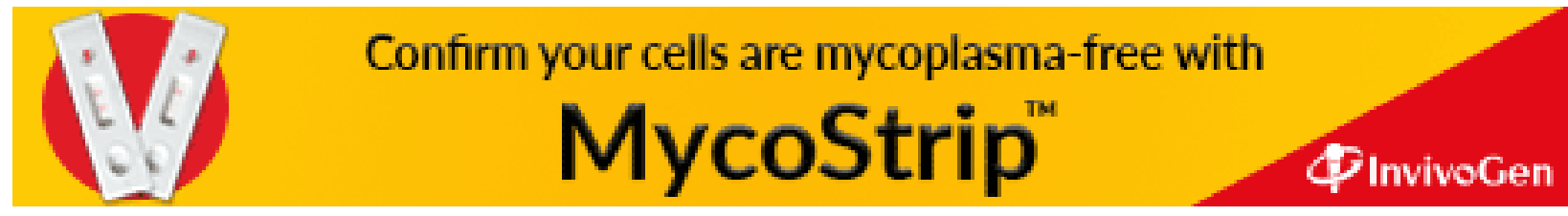

